\title{
Thinking on the path of College Students' Ideological and Political Education under the new normal background
}

\author{
Meng-Xi Zhu' ${ }^{1}$, Qing-Nan Meng ${ }^{1,2, *}$ \\ ${ }^{1}$ Beihua University ,Jilin, China \\ ${ }^{2}$ Northeast Normal University ,Jilin, China \\ *Corresponding author:Qing-Nan Meng(meng-qn@126.com)
}

Keywords: New normal; college students; ideological and Political Education

\begin{abstract}
How to innovate the mode of Ideological and political education for college students to meet the new normal background is one of the key contents of the current college students' work. The ideological and political education of College Students under the new normal must be based on the current educational reality, and at the same time, we should start from four aspects: concept, content, method and management, and put forward effective paths for the current ideological and political education of college students.
\end{abstract}

\section{The proposal of "new normal"}

In May 2014, general secretary Xi Jinping conducted an investigation in Henan, pointing out: "China's development is still in an important period of strategic opportunities. We need to enhance our confidence and start from the phasing characteristics of China's economic development to adapt to the new normal and maintain our usual mindset in strategy." However, from the universal value of the "new normal" concept, we should not restrict it to the economic field, but we should practice in all sectors of society, and we should dig deeper into its universal value. With China's economy and society entering a new normal situation, the development of education is also entering a new normal. Here, the so-called "new" is different from the past; the "normal" is a relatively stable normal state. The "new normal" is the normal state of the past and relatively stable. We should take the initiative to adapt to the new normal, because "the new normality will bring new opportunities for development to China". We should set up a "new normal" view of Ideological and political education of college students, innovate the mode of Ideological and political education, and improve the effectiveness of Ideological and political education of college students.

The characteristics of College Students' Ideological and Political Education under the new normal background

The ideological and political education system of college students is increasingly open and pluralistic. Traditional ideological and political education is very closed, each school is independent to carry out ideological and political education of college students themselves within the school, have specialized teachers, internal unified teaching mode of Ideological and political education in Colleges and Universities under this model this level did not communicate too much and discussion, resulting in a closed system. But now is different, as society has entered a new norm, higher education has entered a new normal, every corner of the world with each other in the 
information transmission and real-time transmission system, the ideological and political education has become one of the main open state characterization of Ideological and political education of College Students under the background of the new normal.

The ideological and political education environment of college students is becoming more and more complex and changeable. With the development of social economy and technology, various situations in society are becoming more and more complex. Naturally, college students' Ideological and political education is becoming more and more complex. With the gradual opening of society, the diversification of science and technology and the rapid development of the network have caused major changes in the students. The university is no longer the ivory tower before. Now the universities and the society and enterprises have set up a series of mature networks. The range of activities of college students is no longer confined to universities, and has many interactions with the society and enterprises. In the process of interaction, many bad manners begin to influence the students and challenge the education of the school, which leads to the increasingly complex ideological and political education of college students.

The mode of Ideological and political education of college students tends to be comprehensive and diverse. Under the new normal background, there should be corresponding educational content and educational mode for college students' Ideological and political education, and there are also excellent teachers to teach. However, the traditional mode of Ideological and political education of college students is mainly theoretical guidance and teaching materials of paper reading, is dedicated in the ideological and political class according to the specific teaching materials for college students' Ideological and political education assessment, and finally through the theoretical examination of the way. The degree of students' mastery of ideas depends only on the assessment of the last test paper, but it can't really evaluate how many students have internalized their knowledge. And the present college students' Ideological and political education is no longer so, but in all aspects of coordination and coordination, multiple evaluation.

\section{The path of College Students' Ideological and Political Education under the new normal background}

Renewing ideas and improving the ideological and moral qualities of the University in an all-round way. Ideological and moral education includes ideological and political quality, intelligence quality, physiological quality, psychological quality and so on. College Students' Ideological and political quality is the core of the ideological and moral education, is a general term for the students' ideology and moral quality of the ideological and political quality of college students; mental quality is an important part of the overall quality, composed of knowledge system and ability of the system, the two mutually related and dialectical unity, to a key role in the development of college students; the college students' physical quality is the basic content of the ideological and moral education, the effectiveness of College Students' physical function and life activities, is an important guarantee for college students' growth and success; psychological quality of college students is the key content of the ideological and moral education of college students, to treat themselves and the surrounding environment of the views and understanding, it is rooted in the individual mind, and by the society the guidance of values, is the overall contains intellectual and nonintellectual factors combine, determines the students comprehensive, holding The internal motive force of the continued development. In general, the thought of various elements in moral education is an organic whole, which plays a very important role in the growth and development of college students promote each other and influence each other, should be to cultivate and develop the four qualities in the equally important position, culture can not be separated to strengthen certain 
qualities, thus to promote the all-round development of College students.

Make use of new media to enrich the content of Ideological and political education for College Students. With the rapid development of science and technology, new media to modern network technology as the representative of the students over time and space boundaries whenever and wherever possible for independent study, get real-time information, provide more channels for students' study and life, has also played a very important role. The development of new media has brought more abundant educational content to the ideological and political education of college students. On the Internet platform, we should create a new position of Ideological and political education, accelerate the pace of the construction of red website, and expand the moral way of educating students through the use of healthy websites. Of course, after the establishment of the online platform, it cannot be without the following, or a long time to update a message, and naturally cannot attract students. On the Internet platform, to create a rich education column, for example, the "Two Courses" education, information education, red column column column and so on mental health education, so as to promote the development of online teaching, interest, ideology, development and growth in one of the network activity, the official build scientific and reasonable, students are willing to use the network platform. Secondly, colleges and universities should expand energy input and funding for network construction, and actively promote ideological and political education of university students in every corner of universities, dormitories, University canteens and other universities, so as to broaden the space and way of Ideological and political education for college students. Finally, colleges and universities can set up online forums, open online opinion windows, correctly deal with problems in College Ideological and political education and solve them in time, and provide services for students in an all-round way.

Close to life and broaden the methods of Ideological and political education for College Students. According to the new requirements of the new normal university ideological and political education, we should adhere to the people-oriented and explore the new way of Ideological and political education for college students. Social practice is one of the important tasks for college students to complete in Colleges and universities. Students can understand the world and feel life through a large number of social practices. Therefore, social practice has many functions, such as student's self-education, social education, service concept education and so on. It's also a very important link in the current ideological and political education for college students. Traditional classroom education has been unable to meet the teaching needs of colleges and universities. It needs open education in the field of College Students' Ideological and political education. That is, we should attach importance to students' social practice and take students from class to social life. For example, the use of revolutionary relics, war scenes, great people understand the way of students' patriotism education, compared with the theory in the classroom teaching mode, the way of social practice will give students a more profound impression, so as to effectively enhance the teaching effect.

Forming a joint force to improve the management system of Ideological and political education for College Students. The new normal background, ideological and political education of college students has exceeded the traditional boundaries in the concept of new education and teaching of technical support, extended from traditional school education to the whole society in the scope of time and space, education media also teach the joint development of the social practice teaching, network teaching, classroom teaching is changing from single class. To the Education Department of social work closely, enhance coordination of education, improve the level of Ideological and political education. Units related to schools, families and society of Ideological and moral education plays an important role in the innovation of Ideological and political education 
career, and have their own expectations and the corresponding interest demands to innovation, so innovative work must establish the system of these units related to behavior strengthen education, cooperative ability. First, establish a sound evaluation system, make clear the main stakeholders in the ideological and political education innovation contribution, to provide guarantee for realizing their own interests; secondly, to further improve the evaluation system, to establish the evaluation of teachers' teaching effect on students learning effect evaluation system, urge teachers to innovate teaching methods, improve teaching level; finally, the establishment of a sound information feedback system, the complexity of the ideological and political education of college students in China decided teachers must be able to timely and accurately grasp the students' psychological changes and aspirations in the ideological and political education, and the information feedback in the teaching practice, to carry out ideological and political education, improve the actual effect of teaching.

\section{Acknowledgement}

This paper is the 2016 Jilin Provincial Federation of Social Sciences, "innovative research and exploration of College Students' Ideological and political education mode under the new normal education: taking Beihua University as an example" (no: provincial union 1636-2).

\section{References}

[1] Secretary of Ministry of education. Strengthen and improve the ideological and political education literatures [M]. Beijing: Renmin University of China press, 2005.

[2] Xi Jinping first systematically elaborated the "new normal" [J]. Xinhuanet, 2014-11-09.

[3] Zhang Yaocan, Zheng Yongting, Wu Qiantao and so on. Modern ideological and political education [M]. Beijing people's publishing house, 2006.

[4] Sheng Yun. Research on the innovation of College Students' Ideological and political education model [D]. Dalian University of Technology, 2015.

[5] Qu red, Jia Defang. New media from the perspective of [J]. model of Ideological and political education of College Students under the innovation of Journal of Qilu Normal University, 2013,28 (05): 23-26.

[6] Tao vine, derre, music, Wu Junpeng. 95 after the model of Ideological and political education exploration and Research on the [J]. Education Forum, 2016, (46): 143-144. 